\title{
The Soviet Song Statement of the 1960s-1970s in the Perspective of the Strong Program in Cultural Sociology
}

\author{
Anna G. Ganzha \\ Candidate of Philosophical Sciences, Associate Professor, School of Philosophy and Cultural Studies, \\ Faculty of Humanities, National Research University-Higher School of Economics \\ Address: Myasnitskaya str., 20, Moscow, Russian Federation 101000 \\ E-mail: ann.ganzha@gmail.com
}

\begin{abstract}
The article considers the potential of a strong program of cultural sociology in the research of the Soviet song policy in the 1960s and 1970s. Mass musical genres of the cultural industry era are usually considered in the historicist optics of emancipation and diversification. With such optics, institutional contexts serve only as a background against which the evolution of the post-folklore unfolds. The disadvantage of this approach is the uncritical mixing of the tools of classicist criticism with modern tools of social theory. The Soviet song Estrada formed its own type of song statements by simultaneously rebuilding the institutions of social performance, musical political economy, and aesthesis that served these institutions. Non-reductionist optics, which, from Alexander's point of view lie at the intersection of structuralist and hermeneutical tools, have a pronounced specificity when applied to mass musical genres. The system of intonation combined with the poetic word brought to a state of pure mechanical self-reproduction, according to Adorno, somehow pushes us to describe and decipher the system of meanings of such a product. In order that the search for thickness in the description of musical phenomena does not lead to new reductions, it is necessary to abandon what, at first glance, connects sound with culture, and replace the concepts of "song" and "music" with "song statement" and "musical statement". Using the concepts of "nobility", "authenticity", and "depth" that occupied post-war song discourses, we demonstrate the mechanisms of their circulation within the institute of Estrada in connection with the topoi of song statement that induce social imagination. To do this, we add the attitude for a thick description, in which the cultural meanings supplied by song statements appear in close connection with the Soviet social imagination, to the usual pattern of analysis of the Adornian sociology of smash hits and chamber music forms.
\end{abstract}

Keywords: late Soviet Estrada, late Soviet mass song, song statement, cultural policy, the strong program in cultural sociology, thick description

This study is an attempt to revise various versions of the history of the Soviet mass song. Here we can identify a number of authoritative approaches, each of which exhaustively performs its own interpretive function, but does not grasp the main thing, that is, the relationship between song form and cultural policy. Because of this, the most interesting cases that demonstrate the geometric progression of the topics of the Soviet song Estrada from the 1920 s to the 1970 s remain out of sight. This is a bizarre symbiotic fusion of cultural industries with academic practices, the appropriation of jazz forms and their combination with a conservative request for song statement, the connection of the crooning style of singing with the request for a renewed and sanctioned spirituality of the 
post-Stalin era, another reinvention of folklore, the formation of the image of a folk diva, and so on.

Research interest in this topic is complicated by the fact that the ideological implications of numerous memoirs, interviews, and essays easily penetrate the research field itself and infect the research lasnguage. Almost all Russian studies of Soviet song, with the exception of rare post-perestroika works, suffer from this fatal flaw. The reasons for this lie in the failed transition from dialectically radical methods of cultural research to more flexible and specific approaches related to micro-sociology, micro-history, cultural anthropology, and cultural studies. It is impossible not to take into account the insidiousness of the theme itself-the meaning of the song area was confirmed not only by musical methods and means of direct cultural policy, but also through public discussions which turned into a series of polemics disguised as memoirs, essays, "direct speech", instructions to youth, and political statements.

Another problem is that studies of Soviet song in Russia ${ }^{1}$ fall into the trap of being falsely categorized as "Estrada studies". The difficulty of studying such seemingly simple areas as "Estrada", "jazz", "children's creativity" or "film music" is that there is a symbiosis of self-naming, commercial naming and subject area, which, depending on epistemological intentions, turn different sides each showing us completely different phenomena. The concept of "Estrada" is fraught with the danger of false objectivism, which, under the pretext of fixing and interpreting pseudo-historical events and trying to avoid critical modes of consideration of these phenomena, does not add anything to their true understanding and definition of their real place in the cultural system. From an institutional point of view, studies of Soviet songs fall into a philological and musicological trap: the musical part becomes the object of musicological analysis (however, musicologists themselves avoided such analysis since the song's musical text is usually banal), the poetic part is the subject of philological analysis, which demonstrates its impotence facing the secondary nature of such texts in such cases.

The official censored Soviet song culture of the late 1960s was neither a constructed nor a self-developing phenomenon. It was the product of a complex mix of Soviet cultural policies, public statements, and performative practices. With a few illustrative examples, I'm going to demonstrate that a strong program in cultural sociology (Alexander, 2003, 2006) can be used with a high degree of productivity to frame the concept of a song. Following the guidelines of a strong program should free the field of study of Soviet song and

1. Among the successful works about the song, resorting to a thick description, is the book by Artjoms Šela (2018), dedicated to the genealogy of folk songs in the first half of the 19th century. Oksana Bulgakova (2015) focuses on Soviet timbral and voice politics in her research on the Soviet voice medium. Her optics is based on the fact that the system of power and coercion, combined with technical media and borrowing of Western models, changes voices and creates their special history. Bulgakova creates her own type of thick description of the transformation of Soviet voices, bypassing the moment when public singing turns into public speech. In a strong paradigm, Sergey Zhuk (2010, 2011) writes his works about music in the system of Soviet society, creating a kind of phenomenology of the rock industry in a single city. Daria Zhurkova (2019) sums up the Soviet tradition of studying mass musical genres, without going beyond its language and highlighting not only the song genres themselves, but also separating art from manifestations of sociality, high from low, mass from non-mass, thus acting within the framework of the weakest theories. See also: Fahretdinov, 2018; Raku, 2017. 
songwriting from the trap of naturalism, which, on the one hand, puts the researcher on the side of the carriers of song discourse and makes him a hermeneutist of poetic-ideological-musical fantasies, while on the other hand, locks him in an art-criticism ghetto. The unprecedented Soviet song project was supervised by various administrative authorities who produced a specific discourse, the study of which also requires a strong theory.

Let's see to what extent a strong theory can be applied to a particular phenomenon. For the study of musical processes, weak theories such as reductionist or schematic are traditionally used, with a large number of empirical examples compensating for the weakness of statements. Here is a gap between the sparse field of theory and the oversaturated field of practice. They are held together by force, or mechanically. If such a weak cultural sociology is quite applicable to traditional forms of musical reproduction, then, in relation to the artificial products of cultural policies, it does not have any heuristic benefits, and actually engages only in self-legitimization, parasitizing on sociologicallyrich material. It is the phenomena of mass culture and media phenomena that, like no other, attracts research that replaces the productive structuralist-hermeneutical fusion with an unproductive hybrid of the exegesis of the inner voice of the composer/director/ poet with a formal textual analysis. "Thickness" is intentionally eliminated. Sohor's and Asafyev's works on song are an "honest" example of weak cultural sociology. Asafyev, who in his early period was influenced by neo-Kantianism and Bergsonism, describes the musical form as a process of crystallization of selected intonations passed through the public body. The actors in this selection are both composers and listeners themselves. The song is not just a mass product, but an objective result of certain acoustic social processes and social consensus, for "there is a struggle for a new meaning of music, and therefore a proof of recognition of its ideological significance" (1971: 305). This approach can be strengthened if we rethink the role of media: the song was not only passed through public ears, but also changed its characteristics in the process of rhetorical suggestive design as a public statement, the subject of which has a certain rhetorical ethos and pathos.

In his post-war works, Sohor tries to strengthen weak explanations by using the concept of "the mode of being-ness": the genre completely changes its functions depending on the field of application, whether it is ritual, concert, mass-everyday, or theatrical (1959, 1974). To use Sohor's terminology, the post-war mass song tried to cover all four functions, destroying the specifics of its being-ness, or returning to it in a new quality.

To move away from the functionalist and naturalistic strategies for understanding song and song culture, I will focus on the concept of song statement as a public presentation of a topos. I will understand the formation of a song statement as a process of emancipation and the autonomization of cultural meanings. Using the construction "cultural sociological theory of mystery" (Kurakin, 2019), we can similarly refer to the cultural sociological theory of song statement. Like a mystery, song statement is at the intersection of the rational and irrational, and the affective and normative; it has its own temporality because it acts with delay, and its consequences for society are not at all those that were planned in the course of cultural policies that regulate song practices and song creativity. At first, it seems that the song artist "expresses" himself with the help of a song. But there 
are "favorite songs", "song hits from movies", "songs at the request of radio listeners", all prerequisites and fruit of a symbiosis of cultural and media policies. Everything is ready to turn the song with its pathos of improvisationality, theatricality, and intimacy into an impersonal, abstract public song statement.

In this article, I will try to outline and solve a range of issues related to the Soviet song topics of the post-war period and the connection of the emerging song-thematic canons with Soviet cultural policy. At the beginning of the article, I will demonstrate how the formation of a song statement took place in the early Soviet period, under the influence of what factors and how the conditions for song propositionality were formed. This should lead us to a wide range of questions related to the understanding of song as a special kind of secular religion which acquires the features of universality as a result of the purposeful deconstruction of the system of song genres in the post-war period. The final result of this deconstruction is the persistent cultivation of thematic and performative self-reference as a paradigm of a song statement. The most important issue here is the internal changes in the social ontology of the song, which is determined by the ratio of private and public. These changes can be seen in the example of the transformation of the ethos of the Soviet performer in the movement from the natural-conditioned to the cultural-universal. The obvious timbre-acoustic patterns of male, female, and child are in fact not directly related to gender, age, or any other identity. Such concepts as "nobility", "sincerity", "restraint", and "soulfulness" are more important for constructing the performing ethos. The bearer of these characteristics becomes the ideal medium of the song statement, cleared of all "vulgar" and fully corresponding to the ideal type of "good song". Using the example of Lyudmila Zykina, I will show that the material equivalent of a "good song" is the boundless space of Russia itself, reflected in the bottomless depth of a woman's soul. In the final part of the article, I will indicate the connection of late Soviet discursive practices, which focus on the concept of "good song", with the process of the final formation of the song public sphere.

\section{The Formation of a Song Statement in Early Soviet Musical Culture}

The discussion about mass song after the 1917 revolution has its fixed beginning in Lunacharsky's problematic articles (1981), and the polemics between members of various musical unions and organizations (Nelson, 2004: 95-124; Ganzha, 2014a). This discussion was inspired not only by the declared new tasks facing the new society, but also by a number of implicit circumstances, including an ambivalent attitude to the romantic project, openness, and radicality of the early Soviet cultural policy, and the growth of the theoretical level of adherents of the tradition of melodism, etc.

In the process of its crystallization, the form of the song statement incorporates several varieties of performativity that are closely related to the cultural policies of the Soviet state. First, it is the performativity of the hero of the national-romantic plot. The performative canon of romantic singing is hesitation and uncertainty when entering a song. The singing hero has doubts, refusing for a long time, but if the song draws him into its vortex, 
he cannot stop; his voice becomes stronger, it soars to the heavens, and his face and figure are transformed (cf. Franklin, 2014; Elliott, 2006: 251-266).

Another type of performativity is musical and scenic. Here, the singing shows not a falling-out of everyday life, but a stopping of the narrative, like a caesura in action. The meaning of this stop is to present a social and psychological portrait of the character; it is a play of the mask and the actor's personality, the shining of one persona through another.

Another type of performativity is crooning. Crooning includes the manner of microphone singing, performing with a damped and light sound, singing in swing phrasing, like the singing style of musical's artists and pop-jazz performers (Stephens, 2008; McCracken, 2015). Soviet pop and theater genres add their own specifics here, focusing on the ratio of timbre, intonation, and the manner of highlighting individual phrases and words, clearly or imperceptibly referring the listener to the authority of Western stars. This is a manner of emphasized performativity: before our eyes, a simple song text passes the verification of authenticity which is obtained when the performer passes the word through his heart, when the musical intonation is imprinted in the verbal suggestion.

In general, this fusion of cultural and political interventions, the rhetoric of common sense, the essentialist concept of song, and the fact of universal singing created powerful incentives for songwriting, inventing or re-inventing new song genres, and adapting "bourgeois" pop and jazz forms. The discussions of the 1920 and the confrontations between the RAPM ${ }^{2}$ and the $\mathrm{ASM}^{3}$ were not only a struggle for a correct understanding of the goals and objectives of musical composition, but also accompanied by the crystallization of music as a statement. There is a unique form of "musical response to criticism", in the form of justification, compensation, and correction. One of the most striking cases is Shostakovich's 5th Symphony, with which the composer "responded" to accusations of formalism (Huband, 1990). Both Shostakovich and Prokofiev always did something in response to the accusations, which consolidated the formula-stating modality of the presented work.

The formation of a song statement as a public presentation of a topos is accompanied by the institutional design of such figures as a composer-songwriter, a poet-songwriter, a civic singer, an Estrada performer, a song diva, or a child soloist. The song meaning is separated from everyday practices and becomes an object of rhetorical design. Song topoi cover all areas of the Soviet natural and social world, and their nomenclature is subject to control and administration. The agents of this control were not only administrative and ideological institutions of cultural policy, but also the songwriters and performers themselves, as well as the publicists and journalists associated with the sphere of culture.

From the moment of appearance of a professional song addressed to the general public and intended for performing replication, the processes of separation of the signifier from the signified begin to occur in it. This is also expressed in an increased level of reflexivity when the song becomes the signified itself. The gap between the signifier and the signified is reduced to a minimum, so the song becomes a sign. This process is well

\footnotetext{
2. Rossijskaja Associacija Proletarskih Muzykantov [Russian Association of Proletarian Musicians]. 3. Associacija Sovremennoj Muzyki [Association for Contemporary Music].
} 
illustrated by the description of the process of composition of the March of Merry Lads (Petrov, Kolesnikova, 1982: 36-37): the music of the march was written in advance, but all the texts that could turn this march into a song seemed bad until the lead actor of the film Merry Lads, Leonid Utesov, persuaded the poet Vasily Lebedev-Kumach to come up with new text:

\section{Нам песня строить и жить помогает, \\ Она, как друг, и зовет, и ведет. \\ И тот, кто с песней по жизни шагает, \\ Тот никогда и нигде не пропадет ${ }^{4}$.}

In the same film, the main character of the shepherd Kostya Potekhin performs a song that is an appeal to the Heart. Songs that are built around the topos of the Heart that show similarities to the canso of medieval troubadours (Zumthor, 2003: 192-223) occupy an important place in the Soviet song topics ${ }^{5}$.

\section{"The Religion of Song" and the Deconstruction of the System of Song Genres}

Synchronizing with changing political cycles and different agendas, the work of shaping song discourse and transforming pop and mass genres has not stopped, reaching its peak of ethical significance during the Second World War and the early Thaw, and has been transformed in a bizarre way since the mid-196os. Alternatively, this process can be described as the emerging "religion of song". The song is placed on an unattainable pedestal, becomes overgrown with additional systems of meanings, and serves as a tool for individual and collective introspection. A song is spoken of as an animate and, at the same time, a spiritualizing object; an attachment to songwriting and performance is declared as a measure of humanity and universality. In these kinds of discursive formations, one can trace the reduced techniques of Marxist dialectics which implicitly deals with the essence of man. What is freedom for a person and what is a person for freedom? Is a person looking for a song, or does the song find the person? Does the person live in the heart of the song or does the song live in the heart of the person? Where are the origins of song and singing? What is the mystery of the song's narodnost' (rooted-ness in the folk), and why is this narodnost' being immediately visible? What is the soul of the folk, the song itself or something else? As we can see, any reflection on the song in the post-war period leads to a flurry of questions that do not require any answer. It would be a mistake to call it demagogy or verbal juggling. This collective aesthesis includes "simple workers", composers, poets, journalists, professional performers and amateur participants. The answer

4. The song helps us build and live, / She calls and guides us like a friend. / And the one who walks through life with a song, / He will never be lost anywhere.

5. Cf.: ". . . it is typical that numerous reviews often contain headlines where the word 'heart' is present: 'Song of the heart', 'From heart to heart', 'Song that penetrates the heart',-including foreign ones" (Uspenskaya, 1985: 19). 
is not required; instead, they offer to listen to the song, join in, and touch the song (cf. Bulgak, 1977).

It is noteworthy that each of the publications of the 1960s and 1970s devoted to song and singers, that is, any monograph, pamphlet, digest, or preface to an anthology, repeats the entire range of questions each time. If we do not consider this to be the ornamentation of random rhetorical devices, then we can assume that this is an act of neutralizing the subjectivist principle that post-Stalinist song entails. Radical discourses refer to song universality:

You and I, reader, are witnesses to the birth of the Soviet classics. What will be called this high name is being created before our eyes: in the visual arts, in music and cinema, on the concert Estrada and in the theater. We know the main criterion, the main sign of such phenomena: their universality. They are addressed only to you or me, and yet they belong to many. They have emerged today, before our eyes, and are therefore even more dear to our hearts (Pistunova, 1974: 3-4).

Developing in a socially isolated and, at the same time, aesthetically saturated environment, the Soviet song never tired of reflecting on the problem of the purity of the genre and its relevance to the current situation. The recognition of the social conditionality, fluidity, and flexibility of the song phenomenon did not cancel the close control over the content and design of the song statement.

The Soviet mass culture of the 1960 s and 1970 is also notable for the unusual dominance of forms that fall under the category of "synthetic genres". Synthetism here is not just a combination of certain "pure" genres, but-more importantly-a progressive marginalization, or a departure from the conventional canon. Marginality is becoming a new mainstream, a cultural norm that constitutes a shaky reality called "Soviet society". A typical example is the so-called "author's" (the "bard") song, whose emphasized opposition to official song genres is a powerful symbolic resource that shifts the boundaries of the cultural norm, and sets guidelines for the collective reflection of the entire post-war generation. A bard song synthesizes not so much the "pure" genres of urban romance and the mass composer's song, but different, previously incompatible forms of social semiosis - the production of social meanings. The "heroic" mode of understanding and constructing reality is organically and consistently combined with the "lyrical" mode. The non-canonical and marginal here is not the performance style or poetics as such, but the very ease and freedom in transitions between different meaning-generating registers. The typical bard does not tell the listener anything ideologically alien or ambiguous; his message is different: "Look, I'm a geologist, but I'm a soldier, and a hero-lover, and a philosopher, and an ascetic, and a hedonist, and anyone else, and all this is me, but also you and us". Sociality here is constructed not through the belonging to a closed community with its own special values, but through the freedom to belong to any communities or groups and clubs, including quite "official" ones, and through its marginality and crossborder nature which becomes a new social norm. We would like to contrast our point of view with those researchers who consider the bard movement as a "fight against official- 
dom" (Djagalov, 2009). When the author's song has lost its function of opposition to the official song discourse, it became clearly noticeable that the alternative nature of the bard song statement was exaggerated, and the degree of reverse influence on the form of the "official" song statement was underestimated.

If we turn to the narratives that began to sum up the author's song movement in the second half of the $198 \mathrm{os}$, we will immediately notice that the main motive shines through even in them; it is the opposition to official song structures and topoi, but with the right to preserve the formal character of song statement, even for a specially defined and selected audience.

Yuri Andreev, a historian and activist of the bard movement, tries to define what sincerity is in a positivist way in his 1991 book. He uses the same patterns as the official song rhetoric, but looks for his own arguments, realizing, that without delineation from the Estrada, a dangerous mixing will occur:

The peculiarity of our song and the listeners of our song is that the various channels through which qualitatively different information-rational and emotional-enters our consciousness are constantly correlated with each other... The content of the beginning of our song is immediately, simultaneously with entering the brain, compared with its spiritual meaning, tested not only for truth, but also for sincerity. And it is this truthfulness of feelings, which either manifests itself or does not, that is the highest evaluation measure. The falseness that cuts the ear during the indifferently mechanical performance of, say, a political oratorio will not be compensated in any way even by a perfectly delivered voice of the highest Conservatoire standard. Words about grief that are not supported by a sincere sense of their own grief, words about great love, uttered with a palpable inner yawn, are murderous, according to our criteria, for the work ... Thus, I want to say that the property of lovers and connoisseurs of the author's song to instantly correlate semantic and emotional information is a universal property, only littered and obscured by the average "art professionals" ... (Andreev, 1991: 7-8).

In the end, Andreev concludes that the meaning of the bard movement was to teach a lesson of sincerity and morality to musical figures from another camp: "The strength of our bards is in their desire for truth. In their time, they unobtrusively helped the best of professional composers and songwriters to become in this sense adequate to the requirements of the time. In what way? First of all, in the humanization of their intonation, in their transition to the position of a truly humanistic attitude to a complex person" (237).

For all the inconsistency and heterogeneity of what is called the Soviet cultural policy, the persistent and purposeful cultivation of a system of song genres stands out within its contours. In the post-war years, the appeal to the song gradually turns into a gesture of presentation of the topoi of confession, monologue, plea, an appeal to higher powers, and ballad narration. In the 1960s, two divergent forces became noticeable: the crystallization of song with an endless multiplication of its thematic blocks, and the deconstruction of the song genre. The deconstruction of the Soviet song was not limited to the usual breaks in the film narrative by invading it with song monologues, but also concerned the organi- 
zation of the musical and poetic text itself. Paradoxically organized marginal-mainstream practices of home and friendly music making, which included, for example, Okudzhava (Bulat Okudzhava, 2004), turn into an influential force that Soviet film directors use as an alternative suggestive field, opposing, on the one hand, the usual film suggestion with its inevitable montage, audiovisual obsession, and narrative bias, and on the other hand, the very system of Soviet film policy allowing the use of such self-neutralization gestures. This can be seen in comparing the author's performance of Okudzhava's songs with the arranged orchestral version. The Soviet film policy of the 1960 s and 1980s doubles the system of musical and poetic performativity. This is especially noticeable in the works of Okudzhava and Yuli Kim: their seemingly improvised "silent songs" and "ditty" are loaded with semiotically-complex timbral meanings of jazz and pop-symphonic origin. The vocal style (Potter, 1998) and, as a result, the rich topics of Okudzhava are included in the circulation of Soviet song statements. In his most popular poetic texts in the film industry, we see a variety of types and figures-the fruit of cultural selection of early and late modernity. The Ballerina, the soldier, the trumpeter, the drummer, the sentry, the pirate, and the hussar,-all of them take their places in the auto-reference system of song topoi.

\section{Self-Reference as a Paradigm of a Song Statement}

Soviet narratives focused on the problems of creativity and genres hide the reality of song statement becoming a public presentation of the topoi system. This development was made possible by several factors. The first of these, of course, is connected with the so-called lyric origin and the lyric hero who is instructed to speak and sing in the first person. Up to a certain point, lyrical outpourings were associated only with the presentation of their subjectivity, but in the post-war Soviet period, the possibility of a double statement opens up, raising the "lyrical subject" to the height of true universality. This change was facilitated by the cultural officials who began to dispose not only of song material, but also forcibly form and format various types of musical statements. In the 1920 s and 1940s, the subject finds himself in the forms of a sentimental lover and a herofighter, ready to give his life for his Motherland and for a bright future. The heroic and love modes are mixed to form a canonical song topos that connects the images of mother, mistress, and Motherland.

We are more interested in another stage, the Thaw and post-Thaw, when many varieties of song statements are formed. It is not the lists and nomenclatures of these forms and types that are of interest, but the conditions of their cultural and political production. So, their declared functionality was often the justification for the existence of certain song genres. It was argued, for example, that amateur songs are needed to fully reveal the inner world of the Soviet man. This song empire, consisting of countless composers and amateur authors, was served by an equally large crowd of art critics and journalists. Its task was to naturalize hidden cultural policies. By wishful thinking, they formed a utopian song world with their actors, creative results, the agony of writing, and all of that was called "working on a song". Addressing the problems of genre diversity and aesthetic 
expression served as a tool for reducing and hiding the true meaning of the song form as a generator of social meanings and institutions.

The song's expressive arsenal is so sparse and monotonous that, at some point, the interpretive, hermeneutical part began to seriously outweigh the poetic-musical part. Since the late 1950s, singers and songwriters have been given opportunities for public reflection. A new genre appeared, the "reflections of the song", or the "meditations on the song". This self-explanatory part has grown so much that not only does every composer or performer have to ask themselves what a song really is, but also includes their thoughts in the songs themselves. A "song about a song" was developed, a new type of statement that grew out of the March of Merry Lads. In addition to turning a song or musical number into a formula or performative statement during the Great Patriotic War, important events and discussions begin to occur from the end of 1953. On December 24, 1953, at the Seventh December Plenum of the Board of the Union of Composers of the USSR, the question of the role of light music in the life of Soviet people and new song tasks was raised in a new way for the first time in the history of Soviet composers' plenums. The main report, "On the State and Tasks of Song Art", was read by Vladimir Zaharov, Secretary of the Union of Composers. It begins with the declaration that "the people demand from composers and artists a genuine abundance of musical art in all genres" (1954: 3), and continues:

It is necessary to intensively develop all genres of song art. We need songs that are heroic, lyrical, dancing, and humorous. There are no bad genres-each genre can have real artistic achievements... In our song should sound fun, and joy, and sadness, and love longing,-we do not have the right to regulate the reflection of the living, natural feelings of Soviet people in the song. Both satirical songs and sharp topical verses that attack negative phenomena in our life should sound in full voice. You can't ignore the huge variety of requests and artistic tastes of Soviet people (18).

A long post-Stalin discussion about light music begins. Now, the semantic emphasis is shifting towards its ideological neutrality, non-danger, and even beneficence. Sailors, workers, and residents of the hinterland are represented by excerpts from letters where they either err in their understanding of light music, or find important and correct words to justify it (Muzyka i byt, 1954; Diskussija o pesne, 1954). The participants of the discussion agree that life opens up new limitless opportunities for mastering the sphere of light music and song. Poets associated with the decadent tradition and composers who transfer echoes of Cantorial and Klezmer music culture (cf. Loeffler, 2010) are the first to identify song zones sensitive to expansion, and strengthen the rhetorical, melodic, and affective part of a musical statement. In the biography of the master of Soviet song, Isaac Dunaevsky, an important point is the inheritance of Jewish musical traditions from older relatives. The cantor is not only a lyrical performer who should touch the audience, but also a toastmaster, presenter, and master of the conversational genre. Making this fact of his life hidden, Dunaevsky and many of his colleagues involved in the formation of the Soviet song empire somehow transmitted a tradition that allowed to place a message in 
the song that could comment on the surrounding reality in a universal way. Dunaevsky is one of the first to notice the crisis in the post-war song:

I got a feeling that our Soviet song is on the eve of a big and important leap into a new quality. It is difficult for me to confirm this feeling with facts, but as a person who listens to the song a lot and knows it well ... it becomes clear to me that much of the arsenal of our creative tools and techniques is beginning to go through a stage of serious re-evaluation ... I think on the agenda of our creative day is the question of a story song, a ballad, a romance ... Life expands the scope of . . . schemes (cit.: Pistunova, 1974: 88).

Specialized cinema magazines also write about crisis phenomena: it seems to everyone that the cinema has become silent and stopped singing. It is important for us to note that we are not actually talking about a decrease in song production, but about the redundancy of pure singing and the lack of songs as authoritative statements with a formula structure. Petrov and Kolesnikova write that:

After Kuban Cossacks and Tales of the Siberian Land, the song on the screen stopped. And it was impossible to return it by any appeals. There was no room for it until the drama broke the deadlock of conflict-free and varnishing and a living person appeared on the screen again. Then the screen started singing again, but, of course, it was a completely different style of song... Composers and film critics persistently and unsuccessfully tried to persuade each other to return the song to the screen. ... The post-war Soviet song should have been different. The spirit of citizenship, high heroic and Patriotic feelings inherent in it no less than in the pre-war years, required other means of expression (1982: 114).

The new song statement was intended to replace the prevailing "mood of dull melancholy" (Kabalevsky, 1960: 15) melodically, poetically, and thematically from the musical life of the Soviet people, that is, everything private, intimate, and existential.

In the second half of the 1980s, the song statement loses its place and effectiveness. The history of song of the 1960 s and 1970 s is revised, discursively framing it as a movement towards complication, and explaining this by the request of listeners to expand the song content. The song, if we follow this logic, tried to leave the narrow confines of the Estrada and the entertainment world and equalize it with the experimental and academic types of musical statements. The new cult of the performer is not a consequence of borrowing Western practices and trends; it follows from a new type of responsibility of the subject of this complicated song statement (Yasnetz, 1988: 53). The complication refers to the dominance of the ethical and political component which can no longer have the character of a direct ideological statement, but shifts the burden of proving its authenticity to the performer himself. 


\section{The Social Ontology of Song Statement: From Private to Public}

Since the end of the 1960s, major Soviet publishing houses have been publishing a significant number of books featuring biographies of song performers and authors. Among these books, there are also monographs about national song schools, comprising French, American, Russian pre-revolutionary, etc. (Nestyev, 1970; Erismann, 1973; Shneerson, 1977). Their pathos is that a good song is declared international, and a bad, bourgeois, ugly, no-longer-humanized song is an instrument of manipulating and corrupting the tastes of young people. A "good" song is one that is responsible and meaningful. If we are talking about pre-revolutionary Russian song, it should grow from the very depths and represent the folks in its entirety. This completeness is verified by whether the song statement contains the fullness of a restrained experience of suffering or unrestrained and sincere joy. In the songs of American people, traces of political statements are also found. A meaningless and useless song is usually a gesture, while a meaningful, hardwon, and heartfelt song is a statement. Special attention, starting with the Thaw, is paid to the French song. The French song, unlike other phenomena of mass culture and songs of other capitalist countries, appears to be absolutely safe. It is credited with a strong tradition: it is guided not only by individual performers, but also by the organizers of ideological control. French artists come to major cities on tour, their records are published by the record label Melody, and their songs are regularly broadcast on Soviet radio. Sentimentalism, a focus on clear recitative articulation and intimate whispering into the microphone not only serves as a reason for its copying by Soviet artists, but is also absorbed as a genuine model. Guy Erismann's book, published in Russian (1973), is perceived as ideologically close and understandable. Its main lesson, from the point of view of the editor and author of the preface (Grigori Shneerson), is the victory over the temptation of entertainment, and the entertainment format is a rejection of the opportunity and the right to speak (5-12).

Public comments about song and singing at this time are reduced to the fact that the soulful and sentimental within reasonable limits can help strengthen the ideals of society, and establish a reasonable and spiritual life. There is no reason to reject the intimate. In the anthropological perspective, a sincere, vulnerable, emotional person is closer to the civic ideals of the Thaw and post-Thaw time:

The propaganda of the ideas of communism should be close and understandable to the workers, should have a sincere character, reach the mind and heart of every Soviet person, and awaken in him the brightest and noblest thoughts and feelings ... And here we can refer to the last Plenum, which showed that false ideas are still common among some composers, forcing them to treat the warmth, sincerity, and immediacy of emotional expression with some incomprehensible shyness. It is as if they deliberately do not allow a living feeling to break out, hiding it under the armor of deliberate cruelty, contrivance or a pose of gloomy profundity, pretentiously called "the tragic mood" ... (Vysoko nesti znamja kommunizma, 1960). 
Here it is appropriate to ask why traditional sociological, cultural-anthropological, philological, and historical methods in the study of post-war songs work so poorly, and why do they require increased research attention to the life and meaning horizons of participants in the cultural process? The answer to this question requires a presupposition of the ontological heterogeneity of the subject of the song process. Many actors participated in the creation of the Soviet song. These are not only a composer, a poet, a performer, and a listener, but also an official of the supervisory authority, a representative of the party leadership, a journalist, an editor of radio and television broadcasting, and any Soviet person as a representative of their professional community, formal or informal movement, or organization. The judgment of the song statement was made simultaneously from different sides: the same person could speak from different positions and present hardly reducible points of view. Behind the visible collective-song body lies the struggle, opposition, combination, and balancing of various interests and practices under the pretext of singing, writing, managing collective emotionality and taste, preaching, propaganda, entertainment, distraction, mobilization, and so on. In some cases, the song is the collective name, or a phenomenon, or a poetic metaphor, or a therapeutically-political instrument.

I argue that in all cases, high and even inflated requirements for the words, music, and performance of a song are based on a single criterion, that of the need to turn a flowing and self-moving song into a verified and refined statement. This intention can be direct, and then we witness the unification and reduction of the role of the melodic beginning, or it can be hidden, and then we can observe an avalanche-like increase in the requirements for the song. This is felt by the participants themselves-performers and songwriters, as well as journalists, art critics, and other creators of meta-narratives. They feel it, but they articulate it in their own ways. It is important not just to expose these narratives and meta-narratives, but also to show how these processes preserve the horizons of cultural meanings - in other words, to make sure that we are still talking about the song, and not about something else. The Soviet song statement is just such an object where "structuralism and hermeneutics can be made into fine bedfellows. The former offers possibilities for general theory construction, prediction, and assertions of the autonomy of culture. The latter allows analysis to capture the texture and temper of social life. When complemented by attention to institutions and actors as causal intermediaries, we have the foundations of a robust cultural sociology" (Alexander, 2003: 26).

Take, for example, a popular science booklet about lyrics written by the philologist Galina Lubyanskaya (1990). The author writes about the lyrics after the end of the era of Soviet song. She understands lyrics extremely broadly and ascribes all the poems of songwriters to lyric poetry, without making any distinctions for the representatives of academic and mass songwriting. Using the rapidly-losing popularity of the Hegelian methodology, she identifies a certain agitation-lyric style in poetry. This style is problematic for her, so she makes a reservation that by agitation she simply understands the intention of motivation: "Propaganda lyric verse differs in that its hero consciously acts on behalf of a certain social group and offers solutions to socially significant problems. 
At the same time, his individuality, originality as a person is preserved, the lyrical hero is not relegated to the background, but on the contrary, as a 'people's guide' is enlarged to the scale of a social type" (16).

Lubyanskaya calls Mayakovsky the prototype of such poetry, and his successors in the workshop of "agitation-lyric poetry" are the type of texts by Rozhdestvensky, Voznesensky, and Yevtushenko which were actively transferred to songs in the post-Thaw period. Lubyanskaya notes that the Great Patriotic War was the turning point when the poeticsong word undergoes a radical transformation, legitimizing suggestion (26). Finally, describing the situation of impending or accomplished by the 1990 collapse, Lubyanskaya suggests to throw all the forces to keep the lyrics in the public space; she writes that:

\begin{abstract}
The stylistic flow of the classical tradition continues its movement in the vastness of Soviet poetry. Trends in social development now favor it (and lyrics in general). Today, the signs of the spiritual life of the country are the desire to understand the laws that govern the course of events, a return to the original meanings of fundamental concepts, courage and looseness of assessments. In this situation, the price of a personal beginning in the lyrics, creative originality, and extremely sincere expression increases (50).
\end{abstract}

Thus, there is a generally accepted opinion that poetic-song suggestiveness, which borrows its techniques from decadent experiments, acquires the right to publicity precisely during the war years. From pre-war experiments, this literary technique in a complex combination with post-war cultural policies turns into a common place, gaining new opportunities in various cultural practices while remaining a unique tool for forming and asserting one's own subjectivity (cf. Kukulin, 2019).

\title{
The Ethos of the Soviet Performer: From the Natural to the Culturally Universal
}

Now let us look at the ways in which the child, female, and male elements were involved in the orbit of translating a song into a song statement. In the pre-war period, the characters of plays and musical performances most often sang on behalf of the child/animal. In the post-war period, with the development of children's cinema, children's theater, and children's radio and television programs, these subjects were emancipated. They are not given the right to vote-their voice is replaced by an adult or even an adult-female one. The children's solo voices, as they could be heard on radio or television, were carefully calibrated, normalized, and moderated from the timbral, intonation, and performative points of view (Ganzha, 2012). There are a large number of related reasons behind this substitution, but the main one is the refusal to recognize the child's right to have a voice other than the right to make a statement.

The system of children's song statements was formed thematically: by the 1970s, there was a canon of song topoi including environmental, military, revolutionary, pioneer, school, friendship, sports, and animalistic. The special topoi were humorous and satirical. 
The satirical ones exposed the unfortunate consciousness of the dvoechnik (a straight- $\mathrm{F}$ pupil) and were constructed in the form of a self-revealing, self-educational monologue. Jokes could have an existential character and turn into their complete opposite, telling about the expectation of the New Year, holidays, weekends, the arrival of parents from work, hiking, swimming in distant lands, and the dream of finding a pet.

The simplest and most transparent case is the monologues on behalf of a child. These monologues do not coincide with the structure of the children's life or world; amateur children's songs are a rare phenomenon and are usually represented by short songsgames. To direct the child's subjectivity in the song channel, consistent and purposeful steps are necessary. In the 1920 s and 1930s, there was an endless stream of complaints about children singing decadent and vulgar songs. Two tasks are set: the first is to direct children's performances towards getting acquainted with revolutionary and military songs, and the second is to initiate the creation of a dense children's repertoire that meets all the needs of building a new society and educating a new person. The endowment of song subjectivity is not performed out of a desire to make the invisible visible and inaudible audible, but for the sake of granting the right and obligation to make a statement. Here, the suggestion of a song should echo the discovery of the possibilities of this suggestion in one's own voice. If the recording organizer or music director did not confirm the fact of such self-discovery, the song was passed on to an adult woman who now had to find in herself the child who has discovered the suggestive potential of persuasiveness, sincere remorse, infectious joy, and so on. No tasks of socialist construction or education of a harmonious personality, as examples, could in themselves become the basis for the emergence of individualized children's singing.

Throughout the Soviet period, the "natural" part of such social and aesthetic activities was represented by the phenomenon of songs by children-vagabonds, orphans, and beggars. This phenomenon, invisible to the public and not confirmed by the authorities, became visible only in the formats of song and film narration, and most often in their collaboration. The song form in this case is not a frame for creating images, but a way to legitimize the phenomena of suffering, poverty, orphanhood, loss, fear of death, feelings of loss, and a huge range of feelings in the register of the sublime that do not fit into the visible social field. Socialist aesthetics offered crude versions of the sublime as monumental and heroic. On the contrary, the suggestion of the song plays a distancing and performative role here.

The male song statement was formed differently. It may seem paradoxical that it is after the death of Stalin and the Seventh Plenum of the Union of Composers that male singers change into suits and ties. They refuse anything that hints at stage roles, a carnival, or a "musical number". Unusual shirts or trappings and products of designers' imaginations will now only appear on the representatives of the so-called VIA ${ }^{6}$, which, being a sterilized version of the rock movement, are bifurcated by the need to choose between the performative-topical and subjective modalities of the song message. If we use the optics

6. Vokal'no-Instrumental'nyj Ansambl' [Vocal-Instrumental Ensemble]. 
of Alexey Yurchak (2006), the singer's performance and the citizen's performance now enrich each other with performative elements. The singer "performs", i.e., when he enters the stage, he reveals himself and his work to the public, and at the same time, speaks on behalf of a certain social group or raises his voice in defense of something. This speech may contain notes of confession, accusation, presentation, prophecy, visionary, or conversion.

The "diversity" of the Soviet song ${ }^{7}$ which is presented as a task, as a fact, and as material for research (cf. Evans, 2011; Ganzha, 2014b; Cornish, 2019) can actually be considered as a set of possibilities for filling the space of a non-subjective statement that adjures reality. As a unit of such a sacred spell, any verbal formulas could serve; "have you heard how the blackbirds sing?", or "what a good lad you're, Natashka!", or “we have a hunk of bread-and that in half!". Witnesses and contemporaries of this endless song intervention often point out that sometimes they did not understand by ear what these words meant, confused them with others, but sang with pleasure at every opportunity.

If you look at the structural elements of the song statement system, you can clearly see all their conjugations. Whatever aspect we take, whether it is the question of the correct juxtaposition of poetry and music, the permissible measure of vulgarity and a tilt towards a smash hit, stage presentation, work on song material, or the song selection, we can see traces of a consolidated process of giving a song a propositional function. The melodic-rhythmic formulas that Asafyev (1971) or Adorno (1977) concentrate on are also interesting. For Asafyev, the homophonic-harmonic type of melodism is a repeatedly verified and confirmed as the "true formula". This formula-melody is absolutely objective because it is entirely social. For Adorno, the formula of a smash hit is one of the stages of emasculating the content, and an illegal way to fight against time. When Soviet song commentators speculate about where "good songs" come from, they also somewhat repeat similar arguments for objectivity.

In the post-war period, the expression of the "public figure" is increasingly imperceptibly transferred to the expression "music figure", and then to the "Estrada figure". In this case, the performer's responsibility to the trade union, to the public, to citizens, and to the people is emphasized. However, Estrada singers were often recruited from samodejatel'nost' (amateur performance activities) and built their career as an alternative to the main specialty of a turner, locksmith, engineer, so the expression "Estrada figure" refers to the ethos of the song performer as a public presenter of the Soviet topoi system.

Since the 1960 s and throughout the 1970s, there has been a powerful reinterpretation of the pre-war and (partly) pre-revolutionary song heritage. In this process, it can be seen how the song is forcibly given the features of a formula statement. The performer himself can become such a conductor of revision of his own heritage. This happened to Utesov and Shulzhenko, who, endlessly recalling their pre-war and military experience, spent

7. Cf.: "Our people are a singing people. We need different music, different songs. We need different orchestras, from a folk instrument orchestra to a jazz orchestra. We need songs about life, about the fate of people-our people, Soviet people and people of another world, songs about love, about the joy of life, about a beautiful world where peace should reign" (Utesov, 1976: 358). 
the rest of their lives acting as re-actualizers of "old songs". In the pantheon of sacred pop figures, Utesov together with Bernes occupy a special place. In the post-Thaw period, critics emphasize their humanism and ability to convey "quiet" existential truths to the public. The conductor of these truths is the Heart, that is, the substance of song which is electrified and magnetized by suffering and accomplishment. Before preparing to present a song to the public, the late-Soviet singer must allow the song to lie down and mature within himself. Only then will the song substance begin to perform its irreplaceable work and be prepared to become a statement. The statement is a pure form; its content, though important, is only a historically evolving rhetorical convention. The content should not be vulgar since vulgarity can also affect the form.

Since the late 1960s, no one has been shy about talking about the ideal of Estrada intelligence. The singer's intelligence is modesty, depth, and nobility. These three are the qualities of Soviet artists from the "Western" artists. Restraint, nobility, self-control, sincerity, seriousness, soulfulness, and later, spirituality, integrity, complexity, the ability to create spatial images ('song space') and even intelligence are the main features of the rhetorical ethos of the Soviet Estrada singer. Composers whose songs quickly spread among the people and are not a vulgar version of a romance or a thug song are said to be "addressed". ${ }^{8}$ The problem of the addressee in the widespread post-Thaw genre of books about Estrada and circus figures is central, although the wording of this problem looks completely different. For example, biographers of the composer Alexander Kolker (who was able to maintain an effective balance between creativity and business trips to Soviet plants, use jazz and folk elements in a song, combine smash hits with melodic innovations, and form his own thematic policy based on general directions recommended for a specific historical segment) name narrativity and the ability to diffuse (characteristic of the so-called "earworm") among the positive characteristics of his work. The composer himself credits the successful addressing with the scale of the song's diffusion: he would say that "the composer feels joy in any case. But it's especially nice when the song is hummed ... When your song is sung not by a professional performer, but by someone on the tram platform, just on the street-I think this is the highest bliss! It can't be higher than that" (cit.: Yasnetz, 1988: 32).

\section{Lyudmila Zykina: the Russian Woman as the Body of Soviet Song}

In the 1970 and 1980 s, special attention was paid to the mysterious characteristics of the ability to create song spaces and draw spatial images. Indeed, some of both men's and women's songs are so meaningless that they can only be said to "paint" space. This is the space of Russia or of the native land. Lyudmila Zykina has a unique ability to "sing out" the space. Pistunova writes that: "And in fact, she sings only those songs in which there is spatiality ... It conveys the elements-with a pagan delight in their power and beauty,

8. Cf.: "Kolker is attracted to a song with a built-up plot-a story song, a tale song, a narration song. It is always addressed to the audience, unthinkable outside of the addressee. The narrativity grows out of the tradition of Russian Soviet song classics" (Yasnetz, 1988: 31). 
with a civilized knowledge of the power of man over them ... She reincarnates in these elements, which she sings about, she herself seems to be the Volga, the Russian field, or the snowy steppe. Playing off in her singing the space of Russia itself, she endows it the status of a legend" (1974: 123).

To speak out about one's native land is to sound out simply by pointing out its existence. It should be noted here that the Khrushchev Thaw, as an alternative to dissident movements, provided unlimited opportunities for the cultivation of national and cultural identities through the recombination of cultural meanings circulating in society. This adapted folk wave had a wide variety of manifestations while legitimizing itself, including through echoes of Western neo-folklore and playing with musical "nationalisms" (Olson, 2004). The late 1960 s and early 1970 s were a time of not only an aestheticized folk revival, but also of a softening of the laws on childhood and motherhood, a new stage of women's urban emancipation, and informal quotas for women's leadership positions in the direction of increasing them. With the example of Zykina, you can see how the female song statement was formed during these years.

It should be noted that it was in the 1970 s that a curious phenomenon formed-a concert was held for the delegates to the party Congress, members of trade unions, and representatives of various departments. It was an honorable, responsible, and monetary mission, which, in addition, allowed the establishing of informal relations with regional and central functionaries and officials. The candidates vying to become singers had to meet the requirements of seriousness and representativeness; they had to be charming, sociable, sincere, simple people, but most importantly, have the ethos of a song rhetorician who set the tone for the performance from the tribune to others. Zykina fit all of these characteristics perfectly. She, like any other Soviet singer who was "given the road" and being promoted, attracted successful and approved composers and poets. This allowed her to maintain some financial and personal freedom and uphold the highest degree of personal and creative inspiration. Zykina recalled that while performing the duties of an ordinary chorus girl in the Pyatnitsky choir, they were taught not so much to sing as to speak. To speak was to use the song as a public platform:

The Pyatnitsky choir became a school for me in learning Russian songs and the secrets of their performance... I was very lucky-my first teachers were such experts in folklore as the leaders of the Pyatnitsky choir-composers Vladimir Grigoryevich Zaharov and Pyotr Mikhailovich Kazmin. Zaharov ... demanded that we comprehend not only the plot of the song, but its meaning, its deep content, which is formed on the basis of the organic unity of words and music... Zaharov demanded that we comprehend the wisdom of the song ... Zaharov said: a song is a great public tribune, a song can lift people, inspire them, express their feelings and dreams. ... in a song, you need to be able to reflect. ... From the very beginning, you need to know for sure: what is most exciting for you in life? What do you want to say? What problems are you being touched? What is the theme of your work, or, in the language of dramatic art, what is your "supertask"? (Pistunova, 1974: 71-75). 
Critics declare Zykina a researcher of the depths of the female soul. This characteristic is given to the majority of late Soviet official song divas. Zykina reflects on the song, and the process of this reflection never stops. She consistently cleanses the song of any vulgarity that may lurk in its depths: "My way of understanding the soul of a song, if I may say so, is that I live with it, constantly think about it. Slowly I enter its world. Oh, how difficult to sing a song in a right way ... The song invisibly accompanies me everywhere: at home and on the street ... I don't leave it for a minute. At some stage, the song begins to sound in me, and I am intently listening to this constantly ongoing and mysterious process" (80).

All these internal processes of melting the internal into the external have the highest expression in the act of turning the intimate into the public, and in making public the declaration of love. From a deeply personal sense of shame, Zykina's love becomes a universal possession. Zykina herself uses visionary metaphors because she sees the fate of the Russian woman immediately and completely. She is a researcher of life, and in this way, also forms her own type of song statement. In terms of content, this statement is dedicated to the denial of the Sovietism of women-under the Soviet shell, Russia is hid$\operatorname{den}^{9}$. Zykina sets the tone in a female song, emphasizing that the song is an invitation to a conversation, the conversation itself and the expression of the unexpressed: "I always want the song to sound like a confession-heartfelt, pure, free from sentiment, so that in every sung thing there was a heart-to-heart conversation with the listener" (Ibid.).

At the same time, the ecstatic is legitimized on the Soviet stage. It is likely that this is due to the influence of Western music, rock operas and rock musicals gradually penetrating into the auditory world of the Soviet man. This manner gives rise to an interesting collaboration with the civic pathos of the Soviet. In addition, the policy broadcasting deformed the song or rock ballad to pure statement, which in turn, distilled to pure ecstasy: the wave of the chorus of the song Swan Fidelity could sound off in the most unexpected moment-at the construction site, in a kindergarten, or a village house with a rickety roof. Some Estrada singers try to break out of the circle of those who were ready to bear the burden of public statement, and they succeeded. Monologues by Pugacheva and Ponarovskaya are jazz monologues, or romances based on poems by Tsvetaeva or Mandelstam. They present only the personality of the performer, and everything else is carefully etched (MacFadyen, 2001).

9. The article by Günther (1997) about the mother archetype in Soviet mass song explains the types of representations of Soviet women's policies using post-folklore approaches and operates with the concepts of folklore semiotics, hybridized with the revealing strategy of song as a manipulative tool and a tool of mythmaking, where the beneficiary is the power and authorities of a totalitarian society. Nevertheless, this postfolklore approach is the most intense, productive and in a sense "strong". This approach is also presented in the article by Uspensky and Fedotov (2019), however, in relation to the age before emergence of the culture industry. 


\title{
The "Good Song" and the Construction of the Soviet Song Public Sphere
}

A special place in the production of song statements is occupied by the arguments about the origins and criteria of a "good song". We can say that each of the participants in the process had to report on what they understand by a good song, how they make a selection of the vulgar, and what sources they fall to in order to create it. Composer Nikita Bogoslovsky writes that "so far, all attempts by critics to define what a good song is have come to nothing. I think that a good song is not necessarily one that everyone sings, it can also be one that you want to listen to" (cit.: Tarnovsky, 1984: 40). Mikael Tariverdiev talks about the alchemy between poetry and music, which must find each other in order for the song to "take place":

\begin{abstract}
Some profess the complete primacy of poetry, which carries the idea of the work, and in music they see only an "assistant", contributing only to the disclosure of meaning. As a rule, this kind of music is unprofessional ... I believe that vocal music is born from the combination of two equal images-the poetic image and the musical image. When they connect, they must acquire a completely new, third quality, which is not inherent in separate poems and separate music, when they live independently. It is clear that in this case the verses should be verses, not text (cit.: Petrov, Kolesnikova, 1982: 34).
\end{abstract}

Tikhon Khrennikov talks about the song always in terms of insufficiency: "Our poets, unfortunately, give few good song lyrics. It is difficult to find such poems that arouse the desire to sing, write music . . . Let one, even a small topic be taken, but if it is deeply revealed, it can reflect the essence of our wonderful and joyful life. One main theme, deeply felt and exciting, will cause the composer to respond to the main melody. I think a song is born just in that way" (cit.: Grigoryev, Platek, 1983: 136).

The argument about a "good" song now hides not the task of creating an ideologically perfect product, as in Stalin's time, but the task of forming raw song material that, if entrusted to a properly tuned medium, can circulate "from heart to heart":

\begin{abstract}
The art of Georg Ots was distinguished by impeccable taste, simplicity and natural manner of singing. Here's what Georgy Karlovich said: "On stage, I try to show not myself, but the song. After all, a song is a naked human soul ... A singer can be masculine or gentle, harsh or lyrical on stage, but he has no right to be false. Psychological emptiness, pretentiousness, imitation of meaningfulness kills the song in the bud. Then it is not saved by a beautiful melody or a beautiful gesture. My commandment . . . to be myself anytime. Time changes, people change, but such qualities as sincerity, soulfulness, and spiritual depth are always valuable for a person" (Uspenskaya, 1985: 14).
\end{abstract}

An important question is how does the consensus mechanism for recognizing the impermissibility of the vulgar work? Pre-war narratives based on dialectical tools and the influential theories of Asafyev and Lunacharsky helped here. From this point of view, the 
composer should become a knight of the melody-classical and at the same time modern, original and at the same time easily recognizable from the first time-a melody that is immediately ready to become the anthem of today. During the Thaw, the breadth of choice of song material became the basis for a full commentary on reality: the more song topoi, the wider and more complete this commentary. However, the song itself, and this is very important, is able to speak to the audience-you just need to give it the conditions for this. Feltzman writes, "The best examples of Soviet song are characterized by extreme sincerity and soulfulness. This means that they should be sung without any pompous affectation, sentimentality and extravagance. Only the truth of feelings can deeply move the hearts of listeners" (1985: 5).

The general requirement for such performers is restraint. However, in some cases they can use their own strategies-for example, give themselves to the song entirely or carry it like a precious cup:

Performed by Rashid Behbudov folk song becomes an Estrada song and vice versa, it does not seem a paradox ... "Like a precious stone, like a brimming horn filled with old wine, I hold it in my hands when I touch a folk song. It takes your breath away from happiness, from the power contained in it, and delight is replaced by fear: not to break it, not to spill it, to bring every drop of it to people, to turn it so that the sun is reflected in every facet of it" (Koshkin, 1985: 27).

Solving the "riddle" of the song, the agents of song reflection identify the carriers of a concentrated song nature, namely, Leonid Utesov, Mark Bernes, Gennady Belov, Lev Leshchenko, and Iosif Kobzon. They are united by the principle of carrying a noble and intelligent manner of singing. They are reserved, but at the same time, they are at the limit of sincerity, their heart is open to people, their pathos is justified, but they are modest, and they are distinguished by static and a minimum of expressive means with a huge internal intensity. This intensity and this burning gut of the singer allows them to broadcast and express the song itself in any words and any music-to present the song topos as it is. The melody can also be meaningful, so the composer also makes a big contribution here: "The composer's ear discards all the pretentious, sophisticated, and exaggeratedly sensitive things that befits the romance melodism in countless amateur compositions, and selects only the simplest, naturally-sung melodic phrases, subjecting them to light polishing" (Katz, 1988: 202).

These polished melodic phrases together with the suggestive poetic text immediately begin to be replicated and multiplied, filling the Soviet audio-social universe with a complex of hierarchical topics of song statements. They create a song empire that not only comments on any social configurations, events, and even the passage of time itself, but also constructs the Soviet song public sphere. 


\section{Conclusion}

The late Soviet song empire is a complex self-referential system for producing social meanings. The autopoietic nature of this system has not been identified and properly thematized in domestic studies of "popular music", "mass culture", "Estrada art", or "low genres". Any attempts to analyze this phenomenon in art criticism, musicology, or biography inevitably lead to a reduction of the most important component of Soviet song-its propositional and performative functions, and its focus on public presentation of the social topos. No less helpless are research strategies that critically deconstruct the ideological and political content of Soviet song lyrics. As I had hoped to show in this article, the social significance of the Soviet song statement is not limited to delivering an ideological message. The substance of this statement is the entire voiced and sung social world, the architectonics of which is based on the moral and rhetorical design of performative practices, the timbre-acoustic construction of socio-mimetic patterns, and the collective testing of intonation textures of public communication.

The research setting for a thick description of this song world needs methodological optics that correspond to the intentions of the strong program in cultural sociology. In these optics, the most significant characteristics of the late Soviet system of cultural reproduction become visible-the performativity of the practices and institutions included in this system; the structuration of the field of social meanings as a framework of topoi; the universalization of private socio-cultural perspectives in the public sphere of sociopoetic communication; the focus of cultural policy on the modernization of separate, self-preserving cultural practices; the reflexive nature of collective aesthesis; the dialectical interdependence and synergy of "official" and "unofficial" culture; and the ethical legitimation of the aesthetic, etc. Turning to a strong program in the research of the late Soviet cultural and social world will allow us to abandon outdated dichotomous and reductionist approaches, discover new thematic areas, and attract empirical material that has not yet been mastered by anyone.

\section{References}

Adorno T. (1977) Introduction to the Sociology of Music, New York: The Seabury Press. Alexander J. (2003) The Meanings of Social Life: A Cultural Sociology, Oxford: Oxford University Press.

Alexander J. (2006) Cultural Pragmatics: Social Performance between Ritual and Strategy. Social Performance: Symbolic Action, Cultural Pragmatics, and Ritual (eds. J. C. Alexander, B. Giesen, J. Mast), Cambridge: Cambridge University Press, pp. 29-90.

Andreev J. (1991) Nasha avtorskaja..: Istorija, teorija i sovremennoe sostojanie samodejatelnoj pesni [Author's Song of Ours... History, Theory, and Current State of Amateur Songwriting], Moscow: Molodaja gvardija. (In Russian)

Asafyev B. (1971) Muzykalnaja forma kak process [Musical Form as a Process], Leningrad: Muzyka. (In Russian) 
Bulat Okudzhava-His Circle and His Times: A Discussion (2004). Russian Studies in Literature, vol. 41, no 1, pp. 5-59.

Bulgak L. (ed.) (1977) Pevcy sovetskoj jestrady [Soviet Estrada Singers], Moscow: Iskusstvo. (In Russian)

Bulgakova O. (2015) Golos kak kul'turnyj fenomen [Voice as a Cultural Phenomenon], Moscow: New Literary Observer. (In Russian)

Cornish G. (2019) Music and the Making of the Cosmonaut Everyman. Journal of Musicology, vol. 36, no 4, pp. 464-497.

Diskussija o pesne [Discussion about the Song] (1954). Sovetskaya muzyka, no 3, pp. 4958. (In Russian)

Djagalov R. (2009) Avtorskaja pesnja kak zhanrovaja laboratorija "socializma s chelovecheskim licom" [Author's song as a genre laboratory of "socialism with a human face"]. New Literary Observer, no 6, pp. 204-215. (In Russian)

Elliott M. (2006) Singing in Style: A Guide to Vocal Performance Practices, New Haven: Yale University Press.

Erismann G. (1973) Francuzskaja pesnja [French Song], Moscow: Sovetsky kompozitor. (In Russian)

Evans C. (2011) "Song of the Year" and Soviet Mass Culture in the 1970s. Kritika: Explorations in Russian and Eurasian History, vol. 12, no 3, pp. 617-645.

Fahretdinov R. (2018) "Russkaja marsel'eza”: zhestokij romans Petra Lavrova ["The Russian Marseillaise”: Peter Lavrov's Cruel Romance]. Forum for Anthropology and Culture, no 36, pp. 117-153. (In Russian)

Feltzman O. (1985) Pevec i pesnja [The Singer and the Song]. Pevcy sovetskoj jestrady. Vyp. 2 [Soviet Estrada Singers, Issue 2] (ed. M. Uspenskaya), Moscow: Iskusstvo, pp. 5-7. (In Russian)

Franklin P. (2014) Reclaiming Late-Romantic Music: Singing Devils and Distant Sounds, Berkeley: University of California Press.

Ganzha A. (2012) Zvonkoe, gluhoe, travestijnoe: tembroakusticheskoe konstruirovanie sovetskogo jetosa [Voiced, Voiceless, Travesti: Acoustic Design of the Soviet Ethos]. SSSR: zhizn' posle smerti [USSR: The Afterlife] (eds. I. Glushchenko, B. Kagarlitzky, V. Kurennoy), Moscow: HSE, pp. 160-171. (In Russian)

Ganzha A. (2014a) Sovetskaja muzyka kak ob’ekt stalinskoj kul'turnoj politiki [Soviet Music as an Object of Stalinist Cultural Policy]. Logos, no 2, pp. 123-155. (In Russian)

Ganzha A. (2014b) Tematizacija vremeni v sovetskoj massovoj pesne [Thematization of Time in the Soviet Mass Song]. Logos, no 3, pp. 41-66. (In Russian)

Grigoryev L., Platek J. (1983) Ego vybralo vremja [Time Chose Him], Moscow: Sovetsky kompozitor. (In Russian)

Günther H. (1997) Pojushhaja Rodina: sovetskaja massovaja pesnja kak vyrazhenie arhetipa materi [Singing Motherland: Soviet Mass Song as an Expression of the Mother Archetype]. Voprosy literatury, no 4, pp. 46-61. (In Russian)

Huband J. (1990) Shostakovich's Fifth Symphony: A Soviet Artist's Reply...? Tempo, no 173, pp. 11-16. 
Kabalevsky D. (1960) Muzyka i sovremennost' [Music and Modernity]. Sovetskaya muzy$k a$, no 3, pp. 7-27. (In Russian)

Katz B. (1988) Prostye istiny kinomuzyki: zametki o muzyke Andreja Petrova v filmah Georgija Danelija i Jel'dara Rjazanova [Simple Truths of Film Music: Notes on the Music of Andrey Petrov in the Films of Georgiy Daneliya and Eldar Ryazanov], Leningrad: Sovetsky kompozitor. (In Russian)

Koshkin P. (1985) Rashid Bejbutov [Rashid Behbudov]. Pevcy sovetskoj jestrady. Vyp. 2 [Soviet Estrada Singers, Issue 2] (ed. M. Uspenskaya), Moscow: Iskusstvo, pp. 21-31. (In Russian)

Kukulin I. (2019) Proryv k nevozmozhnoj svjazi: stat'i o russkoj pojezii [A Breakthrough to an Impossible Connection: Essays on Russian Poetry], Yekaterinburg: Kabinetny ucheny. (In Russian)

Kurakin D. (2019) The Cultural Mechanics of Mystery: Structures of Emotional Attraction in Competing Interpretations of the Dyatlov Pass Tragedy. American Journal of Cultural Sociology, vol. 7, no 1, pp. 101-127.

Loeffler J. (2010) The Most Musical Nation: Jews and Culture in the Late Russian Empire, New Haven: Yale University Press.

Lubyanskaya G. (1990) Raznolikaja lirika [Diverse Lyrics], Moscow: Znanie. (In Russian)

Lunacharsky A. (1981) O massovyh prazdnestvah, jestrade, cirke [On Mass Feasts, Estrada, and Circus], Moscow: Iskusstvo. (In Russian)

MacFadyen D. (2001) Red Stars: Personality and the Soviet Popular Song, 1955-1991, Montreal: McGill-Queen's University Press.

McCracken A. (2015) Real Men Don't Sing: Crooning in American Culture, Durham: Duke University Press.

Muzyka i byt: chitateli prodolzhajut razgovor o legkoj muzyke [Music and Everyday Life: Readers Continue to Talk about Light Music] (1954). Sovetskaya muzyka, no 2, pp. 105-110. (In Russian)

Nelson A. (2004) Music for the Revolution: Musicians and Power in Early Soviet Russia, University Park: The Pennsylvania State University Press.

Nestyev I. (1970) Zvjozdy russkoj jestrady (Panina, Vjal'ceva, Plevickaja): ocherki o russkih jestradnyh pevicah nachala dvadcatogo veka [Russian Estrada Stars (Panina, Vyaltseva, Plevitskaya): Essays on Russian Female Estrada Singers of the Early Twentieth Century], Moscow: Sovetsky kompozitor. (In Russian)

Olson L. (2004) Performing Russia: Folk Revival and Russian Identity, London: Routledge.

Petrov A., Kolesnikova N. (1982) Dialog o kinomuzyke [Dialogue about Film Music], Moscow: Iskusstvo. (In Russian)

Pistunova A. (1974) Iz serdca [From the Heart], Moscow: Molodaya gvardiya. (In Russian)

Potter J. (1998) Vocal Authority: Singing Style and Ideology, Cambridge: Cambridge University Press.

Raku M. (2017) The Phenomenon of "Translation" in Russian Musical Culture of the 1920 and Early 1930s: The Quest for a Soviet Musical Identity. Russian Music since 
1917: Reappraisal and Rediscovery (eds. P. Zuk, M. Frolova-Walker), Oxford: Oxford University Press, pp. 127-147.

Šela A. (2018) "Russkaja pesnja" v literature 180o-1840-h godov ["Russian Song" in Literature of the 1800-1840s], Tartu: University of Tartu Press. (In Russian)

Shneerson G. (1977) Amerikanskaja pesnja [American Song], Moscow: Sovetsky kompozitor. (In Russian)

Sohor A. (1959) Russkaja sovetskaja pesnja [Russian Soviet Song], Leningrad: Sovetsky kompozitor. (In Russian)

Sohor A. (1974) O massovoj muzyke [On Mass Music]. Voprosy teorii i jestetiki muzyki. Vyp. 13 [Problems of Music Theory and Aesthetics, Issue 13] (ed. Y. Kremlev), Leningrad: Muzyka, pp. 3-31. (In Russian)

Stephens V. (2008) Crooning on the Fault Lines: Theorizing Jazz and Pop Vocal Singing Discourse in the Rock Era, 1955-1978. American Music, vol. 26, no 2, pp. 156-195.

Tarnovsky K. (1984) Kompozitor Nikita Bogoslovskij: jetapy tvorcheskoj zhizni [Composer Nikita Bogoslovsky: The Stages of the Creative Life], Moscow: Sovetsky kompozitor. (In Russian)

Uspenskaya M. (1985) Dmitrij Gnatjuk [Dmytro Hnatyuk]. Pevcy sovetskoj jestrady. Vyp. 2 [Soviet Estrada Singers, Issue 2] (ed. M. Uspenskaya), Moscow: Iskusstvo, pp. 8-20. (In Russian)

Uspensky P., Fedotov A. (2019) Izobretenie social'noj pojezii: ot penija cyganok k “Trojke" Nekrasova [The Invention of Social Poetry: From Singing Gypsies to Nekrasov's “Troika”]. Skladchina: Sbornik statej k 50-letiju professora M. S. Makeeva [Clubbing: Collection of Articles for the 5oth Anniversary of Professor M. S. Makeev] (eds. J. Krasnoselskaya, A. Fedotov), Moscow: OGI, pp. 214-242. (In Russian)

Utesov L. (1976) Spasibo, serdce! Vospominanija, vstrechi, razdum'ja [Thank You, Heart!: Memories, Meetings, Meditations], Moscow: Vserossijskoe teatral'noe obshhestvo. (In Russian)

Vysoko nesti znamja kommunizma [Carry the Banner of Communism High] (1960). Sovetskaya muzyka, no 3, pp. 3-6. (In Russian)

Yasnetz E. (1988) Aleksandr Kolker: Vremja. Sud'ba. Tvorchestvo [Alexander Kolker: Time, Fate, Work], Leningrad: Sovetsky kompozitor. (In Russian)

Yurchak A. (2006) Everything was Forever, Until It was No More: The Last Soviet Generation, Princeton: Princeton University Press.

Zaharov V. (1954) O sostojanii i zadachah pesennogo tvorchestva [On the State and Tasks of Songwriting]. Sovetskaya muzyka, no 2, pp. 3-22. (In Russian)

Zhuk S. (2010) Rock and Roll in the Rocket City: The West, Identity, and Ideology in Soviet Dniepropetrovsk, 1960-1985, Baltimore: Johns Hopkins University Press.

Zhuk S. (2011) Closing and Opening Soviet Society. Ab Imperio, no 2, pp. 123-158.

Zhurkova D. (2019) Slozhnaja sud'ba "prostyh" form: otechestvennaja tradicija izuchenija populjarnoj muzyki [The Complex Fate of "Simple" Forms: The Russian Tradition of Popular Music Studies]. Art \& Culture Studies, no 1, pp. 192-213. (In Russian) 
Zumthor P. (2003) Opyt postroenija srednevekovoj pojetiki [Essay on Medieval Poetics], Saint Petersburg: Aletheia. (In Russian)

\title{
Советское песенное высказывание 1960-х - 1970-х в перспективе сильной программы культурсоциологии
}

\author{
Анна Ганжа \\ Кандидат философских наук, доцент, Школа философии и культурологии, факультет гуманитарных наук, \\ Национальный исследовательский университет «Высшая школа экономики» \\ Адрес: ул. Мясницкая, д. 20, г. Москва, Российская Федерация 101000 \\ E-mail: ann.ganzha@gmail.com
}

Статья посвящена рассмотрению потенциала сильной программы культурсоциологии в исследованиях советской песенной политики 1960-1970-х. Массовые музыкальные жанры эпохи культуриндустрий принято рассматривать в историцистской оптике эмансипации и диверсификации. В такой оптике институциональные контексты выступают лишь фоном, на котором разворачивается эволюция постфольклора. Недостаток такого подхода в некритическом смешивании инструментов классицистской критики с современными инструментами социальной теории. Советская песенная эстрада формировала свой собственный тип песенных высказываний путём одновременного отстраивания институтов социального перформанса, музыкальной политэкономии и обслуживающего эти институты аистезиса. Нередукционистские оптики, которые, с точки зрения Александера, лежат на пересечении структуралистского и герменевтического инструментария, имеют выраженную специфику, если применять ее к массовым музыкальным жанрам. Система интонации в сочетании с поэтическим словом, доведенная, по словам Адорно, до состояния чистого механического самовоспроизводства, так или иначе подталкивает нас к описанию и дешифровке системы значений такого продукта. Чтобы поиски насыщенности в описании музыкальных феноменов не привели к новым редукциям, необходимо отказаться от того, что, на первый взгляд, связывает звучание с культурой, и заменить понятия «песня» и «музыка» на «песенное высказывание» и «музыкальное высказывание». На примере оккупировавших послевоенные песенные дискурсы понятиях «благородства», «подлинности» и «глубины» мы демонстрируем механизмы их циркуляции внутри института эстрады в связи с индуцирующими социальное воображение топосами песенного высказывания. Для этого к привычной схеме анализа адорнианской социологии шлягера и камерных музыкальных форм мы прибавляем установку на насыщенное описание, в котором культурные смыслы, поставляемые песенными высказываниями, предстают в тесной связке с советским социальным воображением.

Ключевые слова: позднесоветская эстрада, позднесоветская массовая песня, песенное выказывание, культурная политика, сильная программа культурсоциологии, насыщенное описание 